\title{
Summer influence of 1 and 2 yr old mussel cultures on benthic fluxes in Grande-Entrée lagoon, Îles-de-la-Madeleine (Québec, Canada)
}

\author{
Marion Richard ${ }^{1,2,3}$, Philippe Archambault ${ }^{1,3, *}$, Gérard Thouzeau ${ }^{2}$, \\ Gaston Desrosiers, ${ }^{3, \mp}$
}

${ }^{1}$ Fisheries and Oceans Canada, Institut Maurice-Lamontagne, Environmental Sciences Division, 850 Route de la Mer, PO Box 1000, Mont-Joli, Québec G5H 3Z4, Canada

${ }^{2}$ CNRS-UMR 6539, Institut Universitaire Européen de la Mer, Technopôle Brest Iroise, Place Nicolas Copernic, 29280 Plouzané, France

${ }^{3}$ Institut des Sciences de la Mer, Université du Québec à Rimouski, 310 Allée des Ursulines, CP 3300, Rimouski, Québec G5L 3A1, Canada

\begin{abstract}
The summer influence of 1 and $2 \mathrm{yr}$ old suspended mussel lines on benthic fluxes (oxygen, silicates, ammonium, phosphates, nitrates and nitrites) was studied in Grande-Entrée lagoon (GEL), îles-de-la-Madeleine, Québec, Canada. This influence and its temporal variation were examined in relation to bottom water, sediment and macrofauna characteristics. In situ mensurative experiments using benthic chambers and sediment cores were carried out at 2 mussel sites (M1 and M2) and 2 control sites (C1 and C2) in July, August and September 2003. In contrast to $1 \mathrm{yr}$ old mussel lines (M1), 2 yr old lines (M2) enriched the sediment in organic matter and increased silicate, ammonium, phosphate and nitrite fluxes at the water-sediment interface. Silicate, ammonium and phosphate fluxes were highest in August, when temperature was highest. The main nutrient releases observed at the water-sediment interface in M2 could reduce nitrogen and silica limitation in the water column. Mussel lines did not influence benthic macrofauna biomass, but favoured the recruitment of many small-sized organisms. No influence of mussel lines was observed on oxygen consumption at the water-sediment interface. Macrofauna biomass and oxygen consumption increased in parallel during the summer, but the respiration of the low biomass alone cannot explain the greater overall benthic oxygen demand. The latter was probably also driven by the oxidation of reduced compounds such as sulfides. The reduced nature of the sediment could be natural in GEL, but the continuous accumulation of mussel biodeposits since 1985 has probably contributed to the degradation of the benthic environment in the mussel farm.
\end{abstract}

KEY WORDS: Mussel line - Biogeochemical fluxes · Water-sediment interface · Organic enrichment · Benthic macrofauna

- Resale or republication not permitted without written consent of the publisher

\section{INTRODUCTION}

Mussels are suspension feeders which remove suspended particles from the water column before producing pseudofaeces and faeces (Navarro \& Thompson 1997, Cranford et al. 2003, Hartstein \& Rowden 2004). The latter rapidly settle to the seabed, especially under conditions of slow or poor water flushing and exchange (Cranford et al. 2003). In addition to the settlement of relatively large volumes of biodeposits, mussel fall-off and shell debris accumulate beneath mussel longlines (Grant et al. 1995, Christensen et al. 2003).

Biodeposition could enhance sedimentation rate which has been shown to be 2 to 4 times higher inside than outside shellfish farms (Dahlbäck \& Gunnarsson 1981, Hatcher et al. 1994, Callier et al. 2006). It could also induce organic matter enrichment of sediments (Deslous-Paoli et al. 1998, Stenton-Dozey et al. 2001, 
Miron et al. 2005) and affect the quality of the particulate organic matter (POM) available for benthic organisms (Grenz et al. 1990, La Rosa et al. 2001). Organic enrichment is known to stimulate biological activity, but also to change the benthic community structure (biomass, abundance and species; Pearson \& Rosenberg 1978, Gray et al. 2002). Since metabolism of the whole benthic community depends partly on macrofauna biomass (Mazouni et al. 1996, Welsh 2003) and abundance (Nickell et al. 2003, Welsh 2003), changes in the macrofaunal community structure will affect the oxygen and nutrient fluxes at the water-sediment interface (Welsh 2003). Indeed, biodeposition has been shown to increase benthic fluxes (Baudinet et al. 1990, Grenz et al. 1992, Mazouni et al. 1996). Therefore aquaculture practices could induce changes in the relative concentrations of silica, nitrogen and phosphorus (Hatcher et al. 1994), thus modifying nutrient ratios (Redfield et al. 1963) and phytoplankton species composition (Smayda 1990). In particular, nitrogen turnover would be accelerated (Christensen et al. 2003).

Bivalve biodeposition (Lerat et al. 1985, Navarro \& Thompson 1997) and mussel drop-offs (Myrand \& Gaudreault 1995) are known to be higher in summer. The higher water temperature and food supply in summer stimulate the metabolic activities of benthic macrofauna (Pearson \& Rosenberg 1978) and bacteria (La Rosa et al. 2001). Consequently, benthic fluxes would be greater during warm periods (Lerat et al. 1985, Mazouni et al. 1996). In summer, intensive bivalve production can induce excessive organic matter loading and critical nutrient releases and oxygen demand in the surrounding water. As a result, eutrophication can favour blooms of harmful phytoplankton (Smayda 1990, Cranford et al. 2003) while anoxia and poisoning of the bottom water (by excessive release and build up of ammonium and sulfide) can cause mass mortality of the whole macrofauna community (Deslous-Paoli et al. 1998, Gray et al. 2002). Excessive bivalve production could induce serious ecological and economical consequences. Assessing the potential impact of mussel farming is thus important for developing an ecologically sustainable management of aquaculture (Danovaro et al. 2004).

Shellfish production by aquaculture is increasing significantly throughout the world (Danovaro et al. 2004). In Canada, the bivalve aquaculture industry has expanded rapidly over the last 2 decades (Cranford et al. 2003). Since the 1980s, the mussel industry has developed in an oligotrophic lagoon (Souchu et al. 1991), called Grande-Entrée, in the Îles-de-la-Madeleine ( $47^{\circ} 35^{\prime} \mathrm{N}, 61^{\circ} 31^{\prime} \mathrm{W}$, Québec, Canada).

Mussels Mytilus edulis L. are cultured suspended from long-lines for a 2 yr grow-out cycle in the Îles-dela-Madeleine. Since Callier et al. (2006) showed that sedimentation rates recorded beneath 2 yr old mussel lines were greater than those beneath $1 \mathrm{yr}$ old lines, a greater influence of $2 \mathrm{yr}$ old mussel lines on the benthic system was expected in this study.

The principal objective of this study was to test and compare the summer influence of the 2 age classes of suspended mussel lines on the oxygen demand, nutrient fluxes (ammonium, phosphates, nitrates, nitrites and silicates) and nutrient ratios at the water-sediment interface. The second objective was to examine the variability of these influences throughout the summer. More specifically, 2 hypotheses were tested: (1) benthic fluxes are greater at the 2 yr old mussel site than at the $1 \mathrm{yr}$ old site, and both mussel sites have greater fluxes than control sites (these fluxes drive changes in nutrient ratios at the water-sediment interface); (2) benthic fluxes are significantly different among experimental dates. These 2 hypotheses were studied in relation to bottom water, sediments and macrofauna characteristics (abundance and biomass).

Although several cohorts of bivalves are usually present in worldwide culture areas, this study is the first to dissociate the influence of different ages of aquaculture structures on benthic fluxes in a coastal ecosystem. The results of this study are expected to be relevant for modelling the carrying capacity of marine ecosystems sustaining bivalve cultures comprising several different age classes.

\section{MATERIALS AND METHODS}

Study area. Grande-Entrée lagoon (GEL) is located on the NE of the Îles-de-la-Madeleine, Québec, Canada (Fig. 1A). The surface area of the lagoon is $58 \mathrm{~km}^{2}$ and the mean depth is $3 \mathrm{~m}$ (Koutitonsky et al. 2002). A navigation channel separates the lagoon into a shallow (1 to $3 \mathrm{~m}$ ) sandy area to the west and a relatively deep (5 to $7 \mathrm{~m}$ ) muddy basin to the east (Koutitonsky et al. 2002; Fig. 1B). An amphidromic point close to the Îles-de-la-Madeleine decreases the influence of the tide, which has a mean amplitude of $0.58 \mathrm{~m}$ (Koutitonsky et al. 2002). In the Îles-de-la-Madeleine, it is frequently windy and wind speeds can reach $15 \mathrm{~m} \mathrm{~s}^{-1}$ (Souchu et al. 1991). As a result, the water column tends to be well mixed (Souchu et al. 1991). West of the channel, current speeds up to $20 \mathrm{~cm} \mathrm{~s}^{-1}$ have been recorded vs. $5 \mathrm{~cm} \mathrm{~s}^{-1}$ in the deeper eastern zone (Koutitonsky et al. 2002). Water residence time in the deeper areas of the lagoon ranges between 20 and $35 \mathrm{~d}$ when tidal- and wind-driven currents are considered (Koutitonsky \& Tita 2006). However, it significantly decreases in winter ( $>40 \mathrm{~d}$ ) when ice-cover (December to April or May) prevents any wind influence on the lagoon hydrology (Koutitonsky \& Tita 2006). In the 


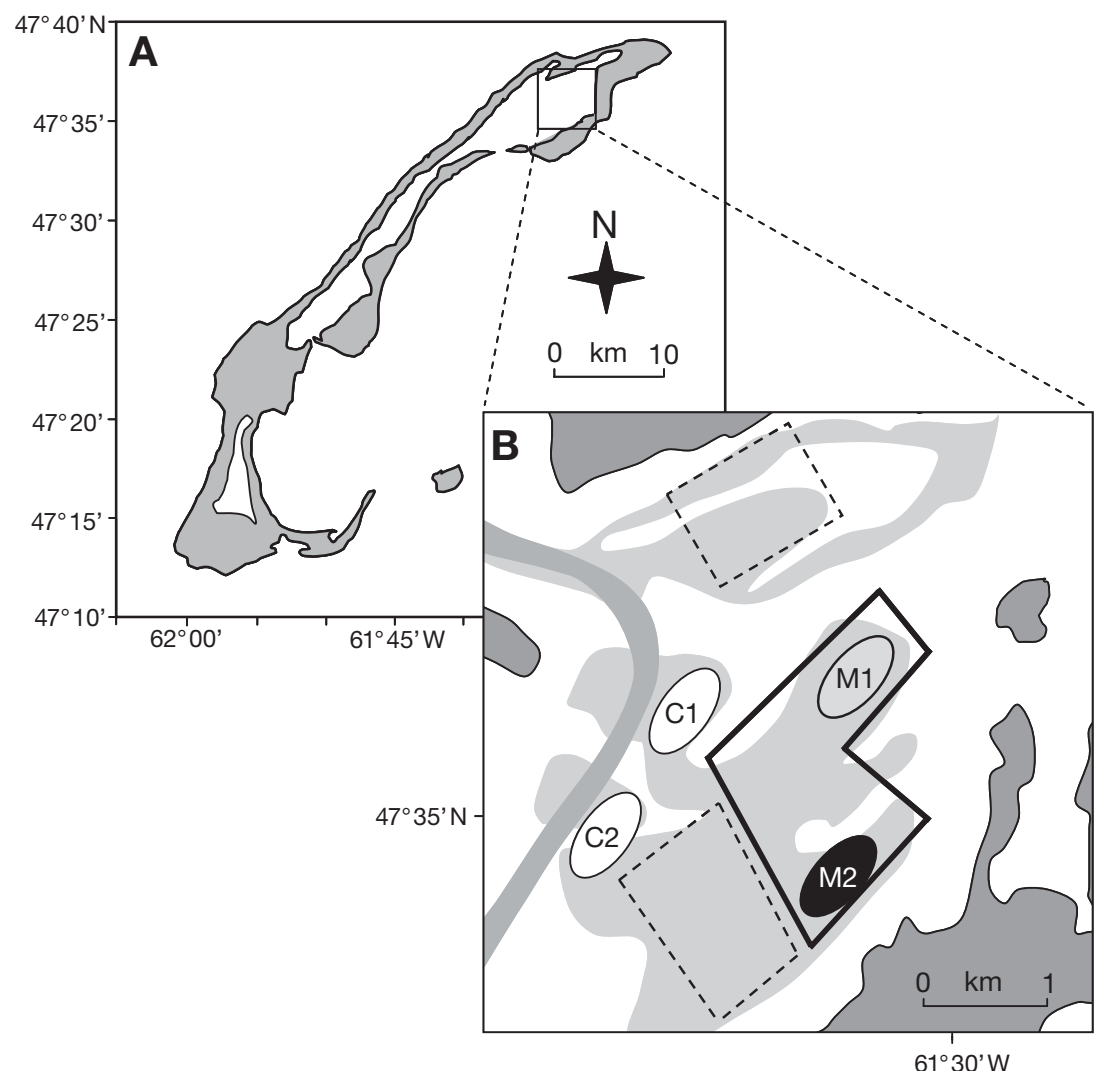

Fig. 1. (A) Îles-de-la-Madeleine. (B) Location of aquaculture farms and experimental sites in Grande-Entrée lagoon; black-contoured polygon: mussel farm location; dash-contoured quadrants: scallop farms (southern scallop farm was unproductive whereas northern farm was productive between 1999 and 2004); ellipses: the 4 sites (C1, Control 1; C2, Control 2; M1, 1 yr old mussel site; M2, 2 yr old mussel site); mid-grey area: channel; light grey areas: deeper zones (mean $6 \mathrm{~m}$ )

mussel farm was separated into 2 distinct zones sustaining 1 yr old (M1: 12 to $14 \mathrm{mo}$ ) or 2 yr old (M2: 24 to $26 \mathrm{mo}$ ) mussel lines (Fig. 1B). The latter are replaced by juveniles $(0+)$ each autumn following harvesting. The mean mussel size was about $4 \mathrm{~cm}$ for M1 vs. $6 \mathrm{~cm}$ for M2 between 5 and 11 August 2003. At this time, mussel dry weight (DW, with shells; $\pm \mathrm{SE}$ ) $\mathrm{m}^{-1}$ line was $1293.08 \pm 212.07 \mathrm{~g} \mathrm{DW} \mathrm{m}^{-1}$ for M1 vs. $1657.28 \pm 373.87 \mathrm{~g} \mathrm{DW} \mathrm{m}^{-1}$ for M2. In 2003, a total of 318 suspended mussel lines representing $114 \mathrm{~km}$ cumulative length were present in the lagoon over a 250 ha surface area (G. Tita pers. comm.). The lines were separated from each other by $20 \mathrm{~m}$. Annual mussel production reached 180 metric tons in 2003. At the end of the 1990s, 2 scallop (Placopecten magellanicus) farming zones were set up in Grande-Entrée lagoon. However, the southern site (130 ha) has never been used for aquaculture, whereas the northern site (100 ha) was productive between 1999 and 2004 (Fig. 1B; G. Tita pers. comm.). During these years, the northern site contained suspended long-lines bearing scallops ranging in total numbers from 1.5 to 3 million individuals (3 age classes; G. Tita pers. comm.).

Experimental design. In situ mensurative experiments (sensu Hulbert 1984), called hereafter 'experiments', were performed in the GEL during the warmest months of the year. In 2003, experiments

lagoon, water temperatures rise on average from $8^{\circ} \mathrm{C}$ in June to $20^{\circ} \mathrm{C}$ in the third week of August before decreasing to ca. $9^{\circ} \mathrm{C}$ by October (Koutitonsky et al. 2002). Salinity is about 30 to 31 from May to August (Souchu et al. 1991). Chlorophyll a concentration ranges between 0.5 and $2 \mu \mathrm{g}^{-1}$ (Roy et al. 1991). Because of the absence of rivers, rainfalls are the only freshwater inputs (Souchu \& Mayzaud 1991). Atmospheric input has been shown to contribute significantly to the inorganic nitrogen cycle (Souchu \& Mayzaud 1991). The lagoon system exhibits oligotrophic characteristics: nutrient inputs could originate mainly from recycling resulting from bacterial remineralisation and excretion by heterotrophic organisms (Souchu et al. 1991).

Since 1985, the mussel industry has exploited GEL (Souchu et al. 1991). Before 2001, suspended mussel lines were deployed in the majority of the deepest zones of the lagoon (Fig. 1B). A few deep zones have never been exploited for aquaculture (e.g. the east zone of the navigation channel; Fig. 1B). In 2001, the were carried out between 20 and 26 July, 18 and 23 August, and 7 and 15 September (hereafter 'July, August and September'). Experiments were performed at 4 different sites: 1 yr old mussel lines (M1), 2 yr old mussel lines (M2), and 2 control sites that have never been exploited for aquaculture (C1 and C2; Fig. 1B). In contrast to many studies (Baudinet et al. 1990, Grenz et al. 1992, Hatcher et al.1994, Grant et al. 1995, Mazouni et al. 1996), 2 control sites were selected rather than one to test the influence of aquaculture with no confounding factor (Underwood 1996). According to several authors (Dahlbäck \& Gunnarson 1981, Mattsson \& Lindén 1983), the influence of bivalve biodeposition would be restricted to a radius of 20 to $40 \mathrm{~m}$ around the farms. In GEL, the mean estimated dispersal of faecal pellets ranges from $0-7.4 \mathrm{~m}(2 \mathrm{yr}$ old mussel) to 7-24.4 m (1 yr old mussel; Callier et al. 2006). During strong wind events, when current velocity can reach $18 \mathrm{~cm} \mathrm{~s}^{-1}$, the estimated dispersion may be up to $19.4 \mathrm{~m}$ (M2) and $24.1 \mathrm{~m}$ (M1) (Callier et al. 2006). The control sites were located more than $500 \mathrm{~m}$ from the aqua- 
culture sites (Fig. 1B) to avoid the influence of mussel biodeposition on the benthic environment. Control sites were separated from each other by more than $500 \mathrm{~m}$. Mean $( \pm \mathrm{SE})$ depth of the experimental sites was $6.14 \pm 0.08 \mathrm{~m}$. Experiments were carried out randomly within sites and among sites to integrate the spatial and temporal variability of our measurements in the whole data set. Three replicates were carried out per site and per date. The total number of in situ experiments was 36 ( 4 treatments, 3 dates, 3 replicates).

Field measurements. Benthic chambers (Boucher \& Clavier 1990, Thouzeau et al. 2007) were used to measure biogeochemical fluxes at the water-sediment interface, rather than peeper and core techniques which are less appropriate (Balzer et al. 1983, Grenz et al. 1991). We used dark instead of transparent chambers to avoid recording photosynthetic activity (Lerat et al. 1990), since this study focused on the comparison of benthic respiration and nutrient regeneration rates between mussel sites and control sites. Benthic chambers were composed of an acrylic tube and a removable acrylic hemisphere. Large enclosures (50 cm diameter) were selected to limit perturbation of the biogeochemical processes by insertion of the base into the sediment, which could damage fauna, funnels and burrows (Glud $\&$ Blackburn 2002). Moreover, the use of large benthic chambers minimises their effect on the spatial heterogeneity of the benthic fauna (Balzer et al. 1983). In addition, the large water volume of the chambers (66 to 781 , depending on how deeply the base was inserted into the sediment) avoids or limits increases in biogeochemical fluxes caused by confinement or water warming.

Each benthic chamber was gently pressed into the sediment by SCUBA divers. The incubation time was set at $3 \mathrm{~h}$, the period determined by a pilot study as the ideal incubation time for measurement of ammonium fluxes and for final oxygen concentrations to have attained levels not lower than $80 \%$ of the initial concentrations (Richard et al. 2006). Each benthic chamber was linked to a submersible pump and to a YSI 6600 probe. The adjustable submersible pumps connected to waterproof batteries provided homogenisation of the water inside the enclosures without noticeable particle resuspension. Water flow in each chamber was adjusted to $21 \mathrm{~min}^{-1}$, allowing stable measurements to be recorded by the YSI probe (Richard et al. 2006, Thouzeau et al. 2007). The latter recorded oxygen concentration ( $\left.\mathrm{mg} \mathrm{l}^{-1} \pm 0.01\right)$, temperature $\left({ }^{\circ} \mathrm{C} \pm 0.01\right)$ and salinity $( \pm 0.01)$ in the chamber at 1 min intervals. This monitoring allowed us to verify if there were any changes in the experimental conditions that could modify the biogeochemical processes in the chamber (e.g. an increase in water temperature).

Water samples were collected with $60 \mathrm{ml}$ syringes at 90 min intervals (start, middle and end of incubation) for nutrient analyses (ammonium, silicates, phosphates, nitrates and nitrites). Three syringes were filled at each sampling to minimise variability in nutrient concentrations. At the end of the incubation, the hemisphere was gently removed from its base. Using $60 \mathrm{ml}$ disposable syringes whose ends had been cut off SCUBA divers collected 6 sediment samples for analysis of the organic matter contained in the top $2 \mathrm{~cm}$. A large sediment core (surface area $262.5 \mathrm{~cm}^{2}$; Wildish et al. 2003) was also collected by SCUBA divers to identify the macrofaunal community.

Sample processing. Sediment organic matter characteristics: Three samples of the top $2 \mathrm{~cm}$ of sediment were dried separately at $60^{\circ} \mathrm{C}$ for 48 to $72 \mathrm{~h}$, weighed, and burned for $4 \mathrm{~h}$ at $450^{\circ} \mathrm{C}$ to calculate ash-free dry weight (AFDW) of the sediment (Byers et al. 1978). Sediment AFDW was measured to the nearest $10^{-5} \mathrm{~g}$ with an AG285 Mettler Toledo balance. Sediment organic matter content is expressed as percent of total sediment weight. Three further samples of the top $2 \mathrm{~cm}$ of sediment were analysed for particulate organic carbon (POC) and particulate organic nitrogen (PON) contents with a Carlo Erba NC 2500 elementary analyser. Finally, POC:PON ratios were calculated.

Macrofauna community: In the field, macrofauna samples were washed over a $0.5 \mathrm{~mm}$ sieve and frozen at $-18^{\circ} \mathrm{C}$. In the laboratory, samples were thawed and organisms were counted to calculate total macrofaunal abundance. Samples were then dried at $60^{\circ} \mathrm{C}$ for 48 to $72 \mathrm{~h}$ and weighed to obtain total macrofauna biomass (dry weight; mg). Dry mass was measured to the nearest $10^{-5} \mathrm{~g}$ with an AG285 Mettler Toledo balance. Abundance and biomass were standardised to $1 \mathrm{~m}^{2}$.

Nutrient analyses: Ten $\mathrm{ml}$ per syringe were immediately sampled in the field to measure ammonium concentration according to the OPA (o-phthalaldialdehyde) method (Holmes et al. 1999) with an Aquafluor handheld Turner Designs fluorometer. Because of technical problems in July, ammonium measurement was performed only in August and September. The remaining water samples were stored in 3 cryovials and frozen $\left(-80^{\circ} \mathrm{C}\right)$ after filtering through $0.2 \mu \mathrm{m}$ cellulose acetate Target syringe filters. Analyses of dissolved nitrates, nitrites, phosphates and silicates were performed on a II PAA II Brann + Luebbe auto-analyser according to Tréguer \& Le Corre (1975).

Flux and ratio calculations. Oxygen consumption was determined from the slopes of the linear regressions established between concentration and incubation time. Nutrient fluxes were estimated from the change in nutrient concentration over incubation time.

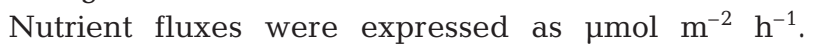
Ammonium, nitrate and nitrite concentrations were summed to calculate total nitrogen concentration for each treatment and date at the beginning $\left(t_{0}\right)$ and at 
Table 1. Results of analyses of variance (ANOVAs) testing effect of: treatment, $\operatorname{Tr}$ (Control 1, Control 2, 1 yr old mussel and 2 yr old mussel sites); date, Da (July, August, September) and their interaction ( $\operatorname{Tr} \times \mathrm{Da}$ ) on bottom water (temperature, salinity, oxygen concentration); sediment (organic matter content, OM, and POC:PON ratios) and macrofauna (biomass, abundance) characteristics. ${ }^{* * *} \mathrm{p}<0.001,{ }^{* *} \mathrm{p}<0.01,{ }^{*} \mathrm{p}<0.05$

\begin{tabular}{|c|c|c|c|c|c|c|c|c|c|c|c|c|c|c|c|}
\hline \multirow{3}{*}{$\begin{array}{l}\text { Variation } \\
\text { source }\end{array}$} & \multirow{3}{*}{ df } & \multirow{2}{*}{\multicolumn{2}{|c|}{ Temperature }} & \multirow{2}{*}{\multicolumn{2}{|c|}{$\begin{array}{c}\text { - Water - } \\
\text { Salinity }\end{array}$}} & \multirow{2}{*}{\multicolumn{2}{|c|}{ Oxygen }} & \multicolumn{4}{|c|}{ Sediment -} & \multicolumn{4}{|c|}{$\longrightarrow$ Macrofauna -} \\
\hline & & & & & & & & \multicolumn{2}{|c|}{$\mathrm{OM}$} & \multicolumn{2}{|c|}{ POC:PON } & \multicolumn{2}{|c|}{ Biomass } & \multicolumn{2}{|c|}{ Abundance, $\ln (x)$} \\
\hline & & MS & F & MS & $F$ & MS & $F$ & MS & $F$ & MS & $F$ & MS & F & MS & $F$ \\
\hline $\operatorname{Tr}$ & 3 & 0.40 & 0.82 & 0.02 & 0.71 & 2.16 & 1.61 & 16.74 & $6.23^{*}$ & 0.36 & 1.44 & 2.39 & 0.11 & 2.1 & $4.84^{* *}$ \\
\hline Da & 2 & 54.14 & $109.71^{* * *}$ & 0.22 & $7.37^{* *}$ & 10.18 & $7.60^{* *}$ & 6.14 & 2.29 & 1.56 & $6.30^{*}$ & 92.31 & $4.36^{*}$ & 16.02 & $36.94^{* * *}$ \\
\hline $\operatorname{Tr} \times \mathrm{Da}$ & 6 & 0.91 & 1.70 & 0.01 & 0.32 & 1.45 & 1.08 & 1.06 & 0.39 & 0.21 & 0.83 & 7.29 & 0.34 & 0.35 & 0.81 \\
\hline Error & 24 & 0.49 & & 0.03 & & 1.34 & & 2.69 & & 0.25 & & 21.19 & & 0.43 & \\
\hline
\end{tabular}

the end $\left(t_{3 \mathrm{~h}}\right)$ of each incubation. Initial and final $\mathrm{N}: \mathrm{P}$ and $\mathrm{Si}: \mathrm{N}$ ratios were calculated in atomic equivalents in August and September whereas Si:P ratios were calculated for all dates.

Statistical treatment. Analyses of variance (ANOVAs) were performed to compare: (1) the characteristics of bottom water (temperature, salinity and oxygen concentration), sediment (organic matter content, POC: PON ratios) and macrofauna (biomass and abundance) (see Table 1); and (2) biogeochemical fluxes (oxygen consumption and nutrient fluxes) (see Table 2) among the 4 treatments, $\operatorname{Tr}(\mathrm{C} 1, \mathrm{C} 2, \mathrm{M} 1$ and M2) and 3 dates, Da (July, August and September with the exception of ammonium fluxes: August and September only). A final series of ANOVAs were also performed to compare nutrient ratios among the 4 treatments $(\mathrm{C} 1, \mathrm{C} 2, \mathrm{M} 1$, M2), different dates (July, August and September for Si:P; August and September for N:P and Si:N) and 2 incubation times, Ti ( $t_{0}$ and $t_{3 \mathrm{~h}}$ ) (see Table 3$)$. Cochran's $C$-test was used to verify homogeneity of the variances (Underwood 1997); when required, data were transformed (see Tables 1 to 3 ). When a source of variation was significant, Student-Newman-Keuls (SNK) pair-wise multiple comparison tests were carried out to identify the differences.

\section{RESULTS}

\section{Bottom water}

Date was a significant source of variation for bottom-water temperature, salinity and oxygen concentration (Table 1). The mean bottom-water temperature showed a significant decrease $\left(>3^{\circ} \mathrm{C}\right)$ from July and August to September (Fig. 2A). The mean water salinity measured in July and August was significantly lower than in September (30.75 vs. 30.98). Finally, the mean oxygen concentration at the water-sediment interface increased significantly from July and August to September (Fig. 2B).

\section{Sediment organic matter}

Treatment was a significant source of variation for the total amount of organic matter contained in the top $2 \mathrm{~cm}$ of sediment (Table 1). The results of the SNK tests showed that the mean organic matter content was significantly higher at the $2 \mathrm{yr}$ old mussel site than at the control and 1 yr old mussel sites (1.5 times higher; Fig. 3A). According to the ANOVAs (Table 1), POC:PON varied significantly among dates. Mean POC:PON was significantly higher in July and August than in September (Fig. 3B).
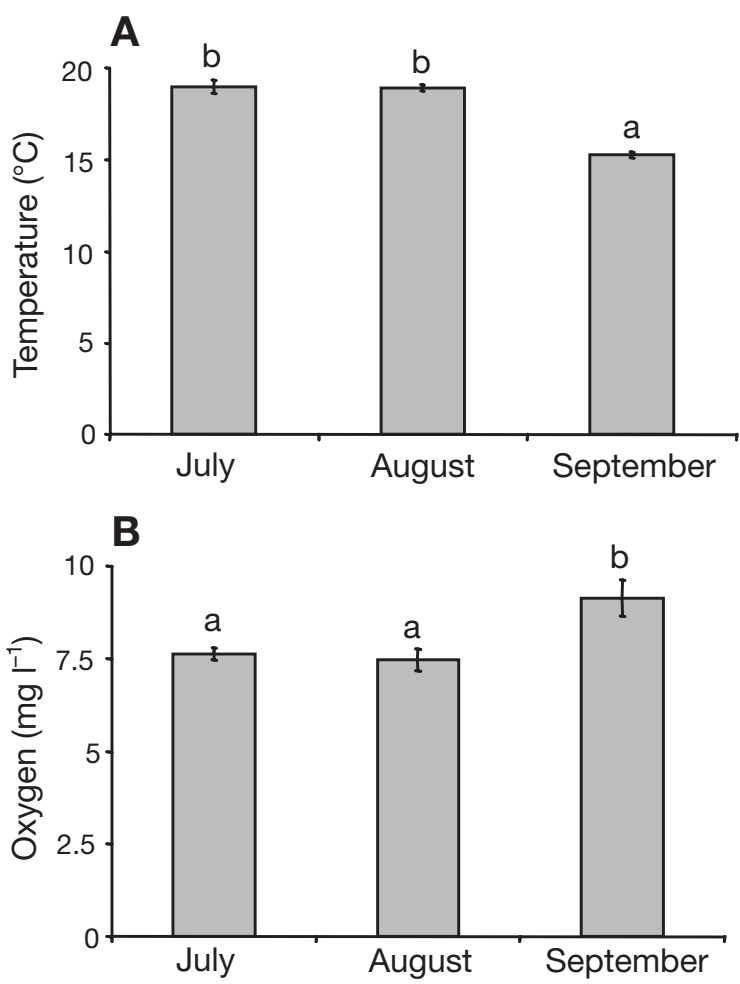

Fig. 2. (A) Bottom water temperature and (B) oxygen concentration at the 3 experimental sites. Different letters indicate statistically significant difference between dates. Data are means $\pm \mathrm{SE}$ 


\section{Macrofauna community}

For total macrofauna biomass, there was no difference among treatments, but date was a significant source of variation (Table 1). The mean total macrofauna biomass was almost 5 times higher in September than in July and August (Fig. 4A). In contrast, treatment and date were significant sources of variation for total macrofaunal abundance (Table 1): abundance was 2 times higher at the mussel sites (M1 and M2) than at the control sites (C1 and C2; Fig. 4B). Mean total macrofaunal abundance increased between July and August at each site (Fig. 4B).

\section{Biogeochemical fluxes}

Oxygen flux was always negative during this study, highlighting oxygen consumption at the water-sediment interface. There were no significant differences among treatments, but date was a significant source of variation for oxygen consumption (Table 2). Mean oxygen consumption was about 3 times higher in September than in July and August (SNK; Fig. 5).

Silicate flux was the highest nutrient flux recorded in this study, reaching $867.58 \mu \mathrm{mol}(\mathrm{SiOH})_{4} \mathrm{~m}^{-2} \mathrm{~h}^{-1}$. The interaction of treatment and date was a significant source of variation for silicate flux (ANOVA; Table 2).
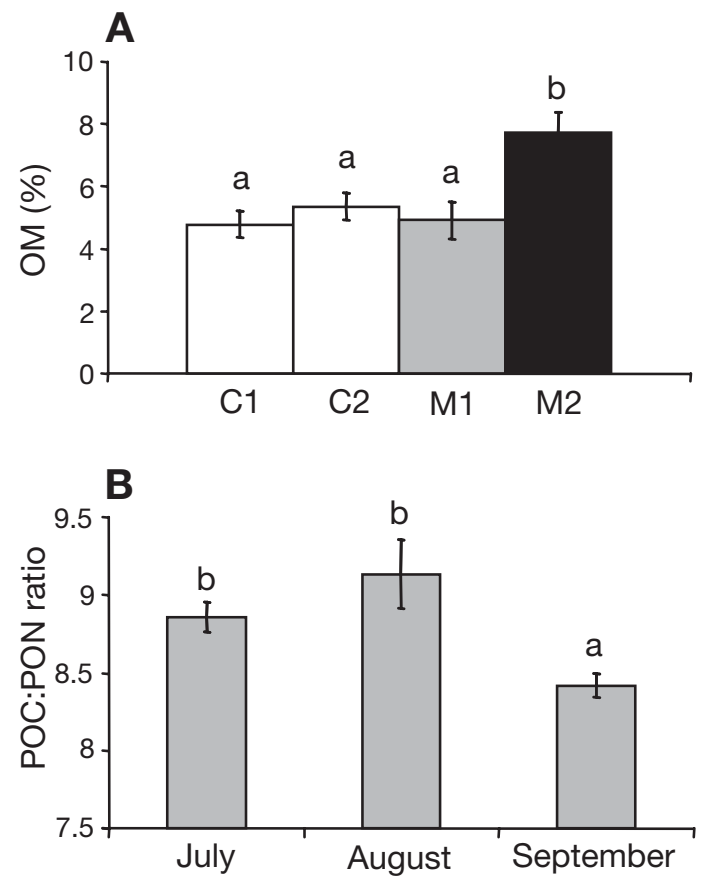

Fig. 3. (A) Organic matter content (OM) of sediment at the 4 sites; (B) POC:PON calculated for the 3 experimental dates: Different letters indicate statistically significant difference between treatments (A) or dates (B). Data are means $\pm \mathrm{SE}_{\text {; }}$ site abbreviations as in Fig. 1
Silicate flux measured at the water-sediment interface of M2 was significantly greater than that measured at control sites (C1 and $\mathrm{C} 2$ ) and at M1 for all dates (Fig. 6). The maximum mean silicate flux observed at M2 was in August and was almost 8 times greater than the maximum mean silicate flux observed in C1, C2 and M1. No significant temporal variation was observed at M1, C1 and C2, whereas silicate flux in M2 increased significantly from July to August and decreased from August to September (SNK; Fig. 6).

Ammonium flux was the second highest nutrient flux measured in this study (up to $448.83 \mu \mathrm{mol} \mathrm{NH} \mathrm{N}_{4} \mathrm{~m}^{-2} \mathrm{~h}^{-1}$ ). As for silicate flux, the interaction of treatment and date was a significant source of variation for ammonium flux (Table 2). According to a posteriori test results, ammonium flux measured at the water-sediment interface at M2 was significantly greater than that measured at C1, C2 and M1 in August and in Septem-
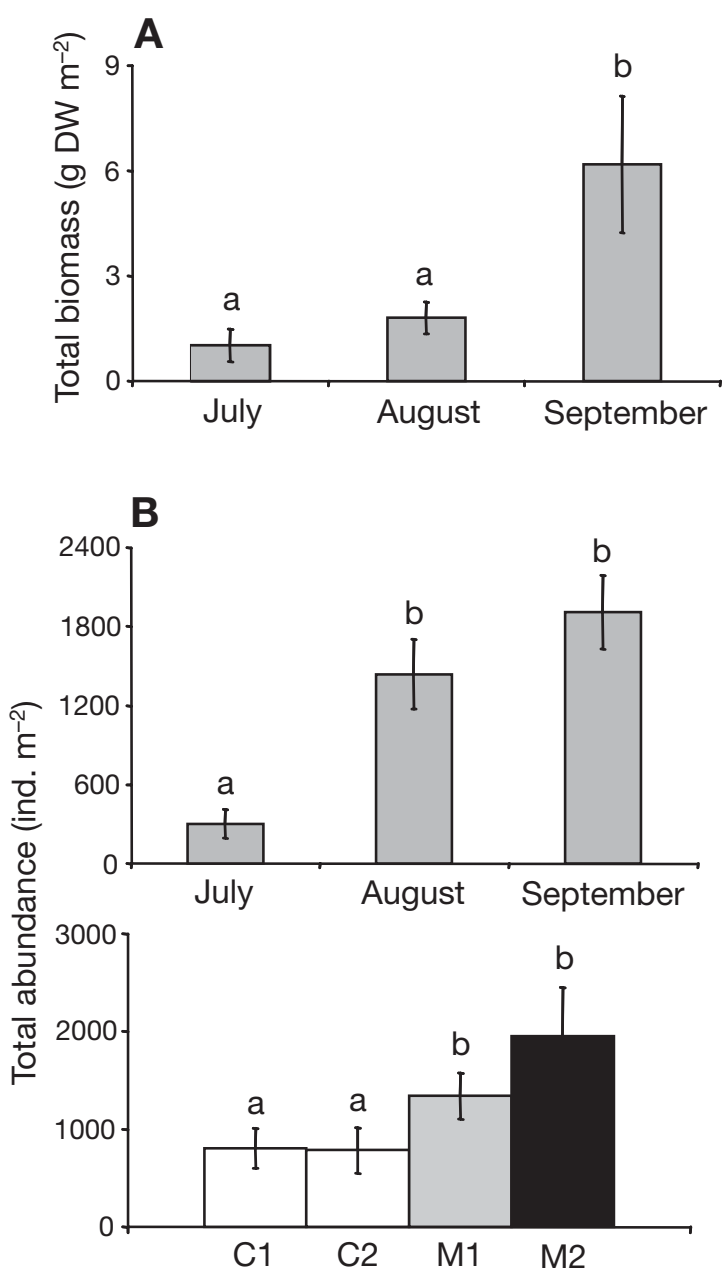

Fig. 4. (A) Total macrofauna biomass and (B) abundance on the 3 experimental dates and at the 4 sites. Different letters indicate statistically significant difference between dates (A and $\mathrm{B}$ ) or treatments (B). Data are means $\pm \mathrm{SE}_{\text {; }}$ site abbreviations as in Fig. 1 
Table 2. Results of analyses of variance (ANOVAs) testing effect of treatment, date and their interaction on oxygen and nutrient fluxes (ammonium fluxes were not measured in July). Abbreviations and significance levels as in Table 1

\begin{tabular}{|c|c|c|c|c|}
\hline Flux & $\begin{array}{l}\text { Variation } \\
\text { source }\end{array}$ & df & MS & $F$ \\
\hline $\mathrm{O}_{2}$ & $\begin{array}{l}\text { Tr } \\
\text { Da } \\
\text { Tr } \times \text { Da } \\
\text { Error }\end{array}$ & $\begin{array}{r}3 \\
2 \\
6 \\
24\end{array}$ & $\begin{array}{r}301.41 \\
329768.05 \\
4872.11 \\
25495.57\end{array}$ & $\begin{array}{r}0.01 \\
12.93^{* * *} \\
0.19\end{array}$ \\
\hline $\mathrm{Si}(\mathrm{OH})_{4}$ & $\begin{array}{l}\mathrm{Tr} \\
\mathrm{Da} \\
\text { Tr } \times \mathrm{Da} \\
\text { Error }\end{array}$ & $\begin{array}{r}3 \\
2 \\
6 \\
24\end{array}$ & $\begin{array}{r}314099.35 \\
35386.16 \\
39377.52 \\
8768.4\end{array}$ & $\begin{array}{r}35.82^{* * *} \\
4.04^{*} \\
4.49^{* *}\end{array}$ \\
\hline $\mathrm{NH}_{4}$ & $\begin{array}{l}\text { Tr } \\
\text { Da } \\
\text { Tr } \times \text { Da } \\
\text { Error }\end{array}$ & $\begin{array}{r}3 \\
1 \\
3 \\
16\end{array}$ & $\begin{array}{r}60844.11 \\
23557.43 \\
9794.15 \\
1405.46\end{array}$ & $\begin{array}{r}43.29^{* * *} \\
16.76^{* * *} \\
6.97^{* *}\end{array}$ \\
\hline $\mathrm{PO}_{4}{ }^{\mathrm{a}}$ & $\begin{array}{l}\text { Tr } \\
\text { Da } \\
\text { Tr } \times \text { Da } \\
\text { Error }\end{array}$ & $\begin{array}{r}3 \\
2 \\
6 \\
24\end{array}$ & $\begin{array}{l}3.12 \\
2.98 \\
1.01 \\
0.50\end{array}$ & $\begin{array}{l}6.20^{* *} \\
5.90^{* *} \\
2.01^{*}\end{array}$ \\
\hline $\mathrm{NO}_{3}$ & $\begin{array}{l}\text { Tr } \\
\mathrm{Da} \\
\text { Tr } \times \mathrm{Da} \\
\text { Error }\end{array}$ & $\begin{array}{r}3 \\
2 \\
6 \\
24\end{array}$ & $\begin{array}{l}1.44 \\
5.01 \\
3.33 \\
2.08\end{array}$ & $\begin{array}{l}0.69 \\
2.41 \\
1.60\end{array}$ \\
\hline $\mathrm{NO}_{2}$ & $\begin{array}{l}\text { Tr } \\
\text { Da } \\
\text { Tr } \times \text { Da } \\
\text { Error }\end{array}$ & $\begin{array}{r}3 \\
2 \\
6 \\
24\end{array}$ & $\begin{array}{l}4.91 \\
0.43 \\
0.11 \\
0.34\end{array}$ & $\begin{array}{r}14.36^{* * *} \\
1.25 \\
0.34\end{array}$ \\
\hline${ }^{\mathrm{a}} \ln (x+1)$ & & & & \\
\hline
\end{tabular}

ber (Fig. 7). Ammonium flux measured at M2 was highest in August and was more than 5 times greater than that measured at $\mathrm{C} 1, \mathrm{C} 2$ and $\mathrm{M} 1$ on the same date. Ammonium flux did not vary temporally in $\mathrm{C} 1$, C2 and M1, whereas it decreased from August to September in M2 (Fig. 7).

Phosphate flux ranged from 0.42 to $128.48 \mu \mathrm{mol} \mathrm{PO}_{4}$ $\mathrm{m}^{-2} \mathrm{~h}^{-1}$. Date was a significant source of variation (Table 2). The mean phosphate flux measured in July

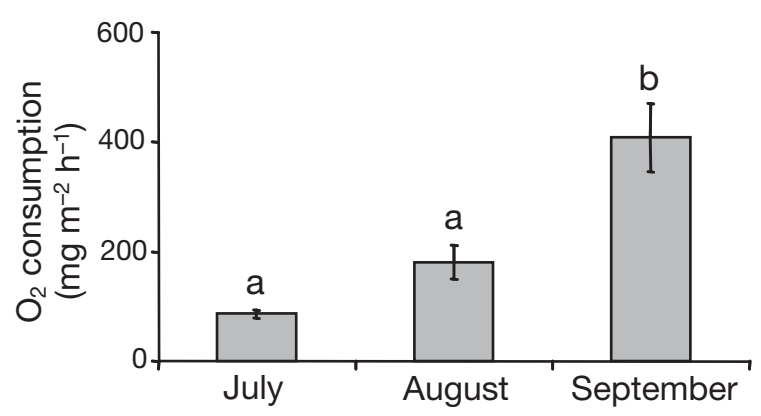

Fig. 5. Mean $( \pm \mathrm{SE})$ oxygen consumption on the 3 experimental dates. Different letters indicate statistically significant difference between dates

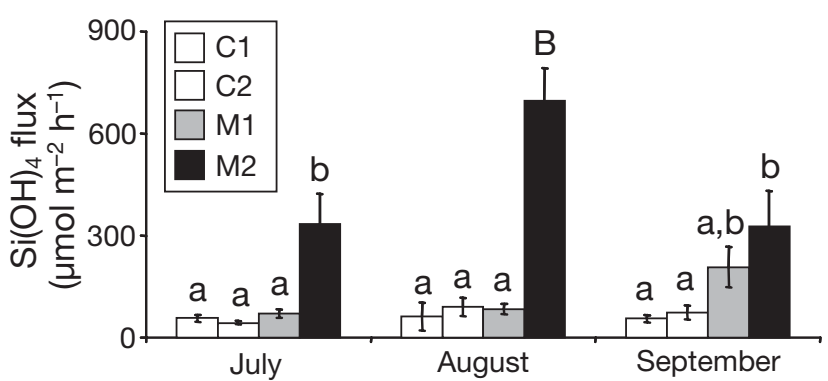

Fig. 6. Mean $( \pm$ SE) silicate flux at the 4 sites on the 3 experimental dates. Different letters indicate statistically significant difference between treatments on a given date; capital letter indicates significant difference between dates for given treatment; site abbreviations as in Fig. 1

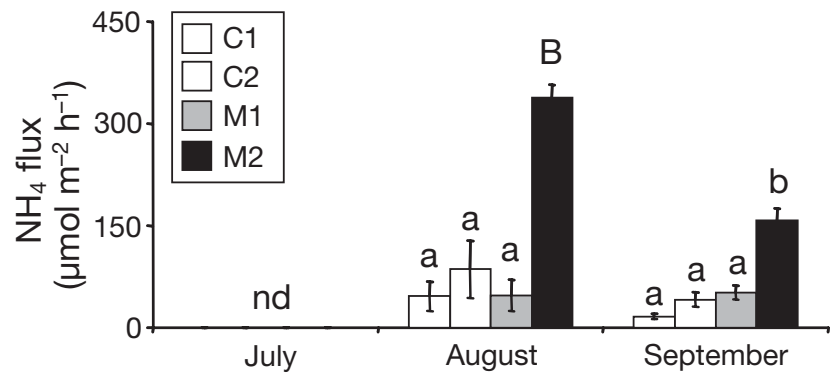

Fig. 7. Mean $( \pm \mathrm{SE})$ ammonium flux at the 4 sites on the 3 experimental dates. Different letters indicate statistically significant difference between treatments on a given date; capital letter indicates significant difference between dates for given treatment; nd: no data; site abbreviations as in Fig. 1

and August was almost 3 times greater than in September (Fig. 8). Treatment was also a source of variation (Table 2): mean phosphate flux was significantly higher at M2, with values 4 times greater than at the other sites for all dates (Fig. 8).

Nitrate flux was low during this study, ranging from -8.25 to $4.52 \mu \mathrm{mol} \mathrm{NO}_{3} \mathrm{~m}^{-2} \mathrm{~h}^{-1}$. No pattern was observed for nitrate flux (no significant source of variation; Table 2). Nitrite flux was also low (-0.43 to 2.44 $\left.\mu \mathrm{mol} \mathrm{NO}_{2} \mathrm{~m}^{-2} \mathrm{~h}^{-1}\right)$, but, in contrast to nitrate flux, a significant difference was observed among treatments (Table 2). Indeed, the mean nitrite flux was on average 6 times greater in M2 than in C1, C2 and M1 (Fig. 9).

\section{Nutrient ratios}

The interaction between treatment and time was significant for Si:P and N:P ratios (Table 3). For both ratios, no significant difference was observed between the initial ratio $\left(t_{0}\right)$ measured at the different sites, whereas the final ratio $\left(t_{3 \mathrm{~h}}\right)$ measured at M2 was greater than that at C1, C2 and M1 (Fig. 10). The final 


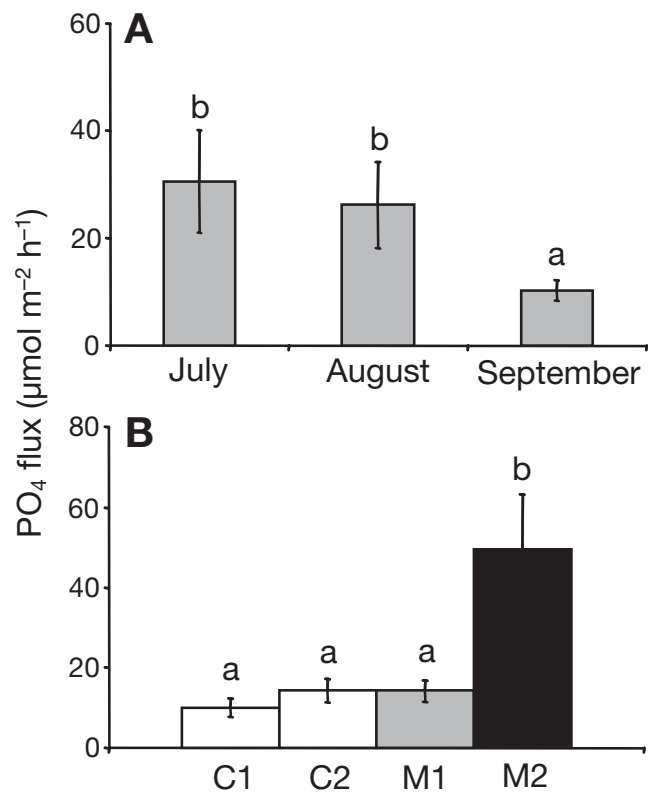

Fig. 8. Mean $( \pm \mathrm{SE})$ phosphate flux at the 4 sites on the 3 experimental dates. Different letters indicate statistically significant difference between dates (A) or treatments (B); site abbreviations as in Fig. 1

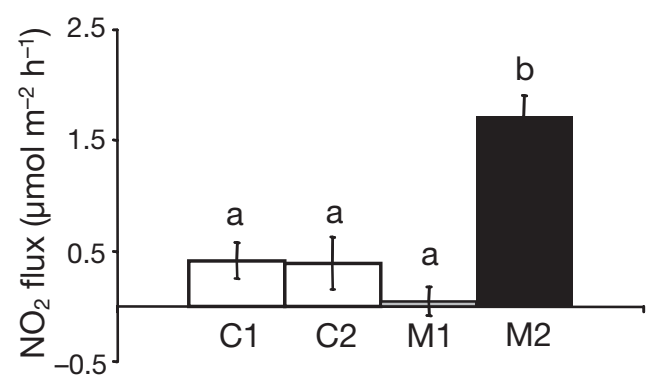

Fig. 9. Mean $( \pm$ SE) nitrite flux at the 4 sites. Different letters indicate statistically significant difference between treatments; site abbreviations as in Fig. 1

Si:P ratio at $\mathrm{M} 2$ was about 1.7 times greater than the initial ratio (Fig. 10A), whereas the final N:P ratio was 3 times greater than the initial value (Fig. 10B). Time was a significant source of variation for the $\mathrm{Si}: \mathrm{N}$ ratio (Table 3). The mean of the initial Si: $\mathrm{N}$ ratio was significantly greater than that of the final ratio.

\section{DISCUSSION}

\section{Influence of suspended mussel long-lines}

Bottom water temperature, salinity and oxygen concentration were similar in all experimental sites. The mean oxygen concentration measured at the watersediment interface ( 7.6 to $9.1 \mathrm{mg} \mathrm{l}^{-1}$ ) during the chamber experiments indicated normoxic conditions, since
Table 3. Results of analyses of variance (ANOVAs) testing effect of treatment, date, incubation time, $\mathrm{Ti}\left(t_{0}, t_{3 \mathrm{~h}}\right)$ and their interactions on $\mathrm{Si}: \mathrm{P}, \mathrm{Si}: \mathrm{N}$ and $\mathrm{N}: \mathrm{P}$ ratios ( $\mathrm{Si}: \mathrm{N}$ and $\mathrm{N}: \mathrm{P}$ ratios were not calculated in July). Other abbreviations and significance values as in Table 1

\begin{tabular}{|c|c|c|c|c|}
\hline Ratio & $\begin{array}{l}\text { Variation } \\
\text { source }\end{array}$ & $\mathrm{df}$ & MS & F \\
\hline \multirow[t]{8}{*}{$\mathrm{Si}: \mathrm{P}$} & $\operatorname{Tr}$ & 3 & 4.8791 & $5.35^{* *}$ \\
\hline & Da & 2 & 47.6704 & $52.30^{* * *}$ \\
\hline & $\mathrm{Ti}$ & 1 & 22.4821 & $24.66^{* * *}$ \\
\hline & $\operatorname{Tr} \times \mathrm{Da}$ & 6 & 4.5118 & $4.95^{* * *}$ \\
\hline & $\operatorname{Tr} \times \mathrm{Ti}$ & 3 & 6.8044 & $7.46^{* * *}$ \\
\hline & $\mathrm{Da} \times \mathrm{Ti}$ & 2 & 5.3111 & $5.83^{* *}$ \\
\hline & $\mathrm{Tr} \times \mathrm{Da} \times \mathrm{Ti}$ & 6 & 0.9368 & 1.03 \\
\hline & Error & 48 & 0.9116 & \\
\hline \multirow[t]{8}{*}{$\mathrm{N}: \mathrm{P}$} & $\operatorname{Tr}$ & 3 & 1.3858 & 2.80 \\
\hline & Da & 1 & 0.4218 & 0.85 \\
\hline & $\mathrm{Ti}$ & 1 & 12.7486 & $25.79^{* * *}$ \\
\hline & $\operatorname{Tr} \times \mathrm{Da}$ & 3 & 1.7232 & $3.49^{*}$ \\
\hline & $\mathrm{Tr} \times \mathrm{Ti}$ & 3 & 2.7212 & $5.51^{* *}$ \\
\hline & $\mathrm{Da} \times \mathrm{Ti}$ & 1 & 0.0009 & $<0.01$ \\
\hline & $\mathrm{Tr} \times \mathrm{Da} \times \mathrm{Ti}$ & 3 & 0.1844 & 0.37 \\
\hline & Error & 32 & 0.4943 & \\
\hline \multirow[t]{8}{*}{$\mathrm{Si}: \mathrm{N}^{\mathrm{a}}$} & $\operatorname{Tr}$ & 3 & 0.3927 & 2.20 \\
\hline & Da & 1 & 0.0591 & 0.33 \\
\hline & $\mathrm{Ti}$ & 1 & 1.2162 & $6.81^{*}$ \\
\hline & $\operatorname{Tr} \times \mathrm{Da}$ & 3 & 0.1775 & 0.99 \\
\hline & $\operatorname{Tr} \times \mathrm{Ti}$ & 3 & 0.2762 & 1.55 \\
\hline & $\mathrm{Da} \times \mathrm{Ti}$ & 1 & 0.1858 & 1.04 \\
\hline & $\operatorname{Tr} \times \mathrm{Da} \times \mathrm{Ti}$ & 3 & 0.0281 & 0.16 \\
\hline & Error & 32 & 0.1786 & \\
\hline${ }^{\mathrm{a}}(x+1)^{2}$ & & & & \\
\hline
\end{tabular}

hypoxia occurs at ca. $6 \mathrm{mg} \mathrm{l}^{-1}$ (Gray et al. 2002). The mussel farms in Grande-Entrée lagoon did not induce oxygen depletion in bottom waters leading to anoxiaas has been observed in oyster farms in France (Deslous-Paoli et al. 1998, Thouzeau et al. 2007). However, organic matter content in surface and subsurface sediments was greater at M2 than at the other sites. As in many shellfish farms (Dahlbäck \& Gunnarsson 1981, Mattsson \& Lindén 1983, Stenton-Dozey et al. 2001), mussel lines in GEL (M2) induced enrichment of sediment organic matter through biodeposition that enhanced sedimentation rates (Hatcher et al. 1994, Cranford et al. 2003). Indeed, the sedimentation rates observed under 2 yr old mussel lines were almost twice as high as those observed in control sites in GEL $\left(\right.$ mean $=34.8 \mathrm{~g} \mathrm{DW} \mathrm{m}^{-2} \mathrm{~d}^{-1}$ at M2 vs. $16.8 \mathrm{~g} \mathrm{DW} \mathrm{m}^{-2} \mathrm{~d}^{-1}$ at control sites in July 2003; Callier et al. 2006). In contrast, no significant enrichment of sediment organic matter was observed at M1 compared to control sites during the summer period. It is possible that the lower biomass of $1 \mathrm{yr}$ old mussels compared to that of $2 \mathrm{yr}$ old mussels was insufficient to induce organic enrichment, as suggested by some authors (Miron et al. 2005). 


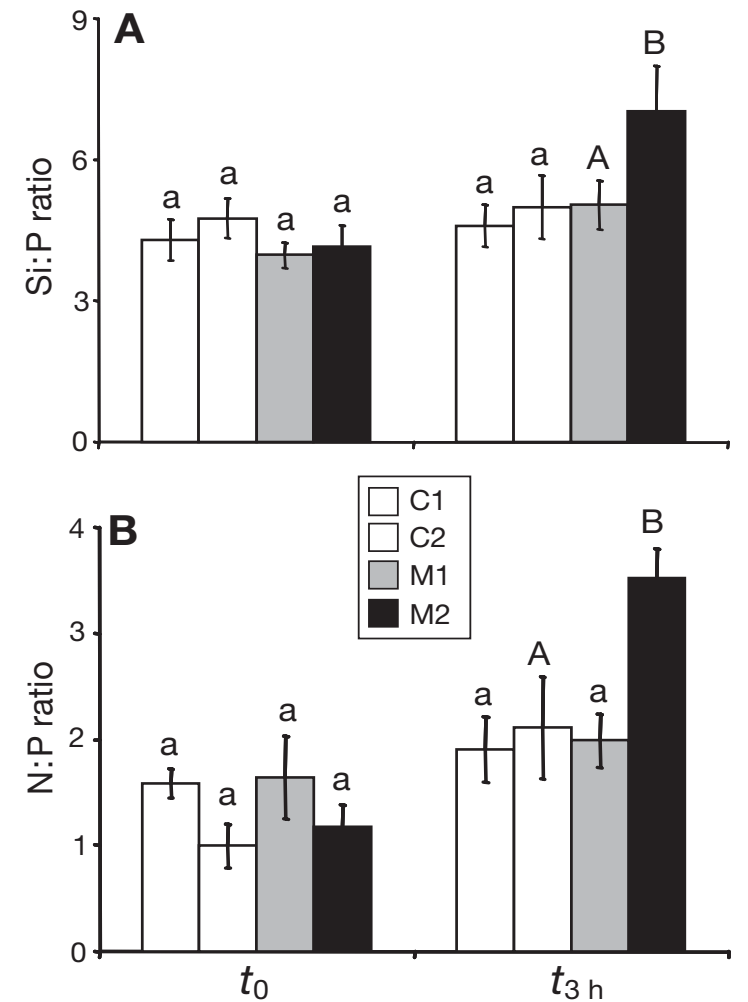

Fig. 10. Mean $( \pm \mathrm{SE})$ of $(\mathrm{A}) \mathrm{Si}: \mathrm{P}$ and $(\mathrm{B}) \mathrm{N}: \mathrm{P}$ calculated for the 4 sites at beginning $\left(t_{0}\right)$ and at end $\left(t_{3 \mathrm{~h}}\right)$ of incubation. Different letters indicate statistically significant difference between treatments; site abbreviations as in Fig. 1

Shellfish biodeposits could affect the quality of particulate organic matter available for benthic organisms (Grenz et al. 1990, La Rosa et al. 2001). The ratio of particulate organic carbon to particulate organic nitrogen (POC:PON) has been used as a proxy for organic matter quality (Nickell et al. 2003). Since nitrogen is degraded more rapidly than carbon, low ratios indicate labile organic matter whereas high values signify refractory organic matter (Nickell et al. 2003). POC:PON ratios between 4 and 8 correspond to phytoplankton, faecal pellets and other easily degraded material of high nutritional value, whereas ratios larger than 10 characterise detritus, sediment or other mineralised material of low nutritional value (Kautsky \& Evans 1987). In GEL, the POC:PON ratios between 8.4 and 9.1 observed during this study indicate fresh or slightly degraded material. In agreement with the findings of Hatcher et al. (1994) at a suspended mussel farm in Upper South Cove, Nova Scotia, Canada, we observed no significant difference between the POC:PON ratios measured in the upper $2 \mathrm{~cm}$ of sediment at mussel sites and those at control sites. The measurement of POC: PON ratios in the superficial (e.g. $0.5 \mathrm{~cm}$ ) layer of the sediment could be a better indicator of mussel farm influence than measurements in the top $2 \mathrm{~cm}$, since most of the particulate carbon and nitrogen that sink to the bottom may not be incorporated into the sediment (Hatcher et al. 1994) and could be rapidly degraded by the benthic community.

Following the Pearson \& Rosenberg (1978) model, or more recently derived models (Nilsson \& Rosenberg 2000, Gray et al. 2002), high enrichment of organic matter through biodeposition could result in the disappearance of large-sized animals (e.g. echinoderms; Mattsson \& Lindén 1983), in biomass decreases (Mazouni et al. 1996, Stenton-Dozey et al. 2001), and in the proliferation of small-sized opportunistic species (Mattsson \& Lindén 1983, Christensen et al. 2003, Hartstein \& Rowden 2004). While 2 yr old mussel lines induced enrichment of sediment organic matter in GEL, no significant difference was observed in the macrofauna biomass between M2 and the control sites. However, macrofaunal abundances in mussel sites (M1 and M2) were greater than in control sites, indicating that individual mass was lower in mussel sites than in control sites and suggesting an increase in organisms of smaller size at the mussel sites. Callier et al. (2006) observed that benthic communities were dominated by small-sized opportunistic species in mussel sites in GEL. These results indicate benthic habitat degradation during mussel culture.

The measurement of oxygen consumption in the water overlying undisturbed sediments is a rapid and sensitive index of benthic community metabolism (Hargrave 1969). Enrichment of sediment organic matter is known to stimulate biological activity, thus increasing oxygen demand at the water-sediment interface (Pearson \& Rosenberg 1978). Indeed, oxygen consumption rates measured under aquaculture structures are often greater than those measured outside the farms (Hargrave et al. 1993, Mazouni et al. 1996, Christensen et al. 2003). Even though organic enrichment and increased macrofaunal abundance were observed in M2, no significant difference was observed for oxygen consumption between mussel and control sites in GEL. According to Grant et al. (1995) and Stenton-Dozey et al. (2001) and contrary to the statement by Hargrave (1969), oxygen consumption is not a sensitive indicator of the impact of mussel culture on the benthic system since it is affected by many factors. Sediment oxygen demand is driven by the respiration of benthic organisms and by the microbial-mediated oxidation of organic matter and reduced inorganic metabolites (Nickell et al. 2003). The relative proportions of each of these processes could be different between mussel and control sites. Further characterisation of aerobic and anaerobic metabolisms using asphyxiation techniques (Van der Loeff et al. 1984) could help to better understand the processes driving oxygen consumption at the water-sediment interface in GEL. 
In GEL, as in other shellfish farms (Hatcher et al. 1994, Stenton-Dozey et al. 2001, Christensen et al. 2003), increased sedimentation rates and organic enrichment observed at the culture sites induced increased nutrient fluxes compared to the other sites. Indeed, silicate, ammonium, phosphate and nitrite releases were 4 to 8 times greater in M2. In our study, silicate releases in GEL were the largest, followed by ammonium, phosphate, nitrate and nitrite releases, as already observed in mussel and oyster farms by Baudinet et al. (1990) and Grenz et al. (1992), respectively. The large silicate fluxes observed at M2 could originate from the dissolution of biogenic silica trapped in mussel biodeposits accumulated at the water-sediment interface (Lerat et al. 1990). Mussel biodeposits are composed of large-sized diatom cells and chain forms (pseudofaeces) or frustules of small-sized diatom cells and chains forms (faeces; Navarro \& Thompson 1997). Diatom tests are made of biogenic silica (Balzer et al. 1983), which could explain the pattern observed in our study. The large ammonium and phosphate fluxes observed at M2 could originate from the decomposition of faeces, pseudofaeces and animal tissues accumulated in sediment, since bivalve biodeposits are usually considered to be an important source of nitrogen (Kautsky \& Evans 1987) and phosphorus (Sornin et al. 1986). Organic matter decomposition with nitrification-denitrification processes induces nitrate-nitrite releases at the water-sediment interface. Nitrification occurs in the upper aerated sediments and denitrification in the deeper anoxic zone (Jenkins \& Kemp 1984). Increased reductive processes (denitrification and dissimilative reduction of nitrate into ammonium) have often been noted in shellfish farms (Christensen et al. 2003). In GEL, the high nitrite fluxes at M2 could be due to these reductive processes. Overall, the high nutrient fluxes observed at M2 highlight the direct influence of mussel biodeposition on the benthic environment. In contrast, biodeposition at M1 may not have been high enough to increase benthic nutrient releases.

Under oyster lines in Thau lagoon (France), Thouzeau et al. (2007) showed that bivalve biodeposition could favour biogenic silica, organic nitrogen and phosphorus retention at the water-sediment interface. High mineralisation rates of biodeposits do accelerate nutrient turnover by massive releases of nutrients at the water-sediment interface, which in turn can modify the nutrient budgets around farms (Baudinet et al. 1990, Thouzeau et al. 2007). The ecological importance of nutrient regeneration is the lessening of nutrient limitation for phytoplankton, which could result in increased primary production and turnover (Smaal 1991). However, disequilibria in nutrient release kinetics can change the original nutrient ratios and the specific composition of phytoplankton communities (Baudinet et al. 1990). According to Redfield et al.'s (1963) theories, normal nutrient ratios for phytoplankton growth are 16:16:1 for Si:N:P, respectively. Any variation in these ratios results in nutrient limitation. In Grande-Entrée lagoon, initial N:P ratios were $<16$, indicating potential nitrogen limitation for phytoplankton production as previously mentioned by Souchu et al. (1991). In the same way, low Si:P ratios $(<16)$ would mean that silicate was limiting in GEL. However, these potential limitations could originate from greater phosphate releases compared to nitrogen and silicate releases at the experimental sites. Phosphate release would be enhanced by the dissolution of ferric oxides and hydroxides in reduced conditions (Balzer et al. 1983, Mazouni et al. 1996). Indeed, low redox values were recorded in the first centimetre of sediment in August 2003 (-67 to -141 Eh [mV], depending on site; M. D. Callier unpubl. data), which indicates hypoxic conditions (Wildish et al. 1999). By increasing $\mathrm{N}$ and $\mathrm{Si}$ releases, mussel-biodeposit remineralisation in the $2 \mathrm{yr}$ old mussel sites induced an increase in the Si: $\mathrm{N}$ and $\mathrm{N}: \mathrm{P}$ ratios, which could reduce the potential nitrogen and silica limitation in the overlying water of this oligotrophic lagoon.

\section{Summer variability}

Sediment organic matter content is partly linked to temporal variations in sedimentation rates (decay of phytoplankton blooms, faeces and pseudofaeces sedimentation) and mussel drop-off. During the summer, the succession of phytoplankton blooms (Roy et al. 1991) and mass mortality events (Myrand \& Gaudreault 1995) are well known in GEL; both phenomena can induce summer variations in organic matter inputs to the sediment. Nevertheless, no variation in organic matter content was observed in the first $2 \mathrm{~cm}$ of sediment in July, August and September 2003. This indicates that either organic matter accumulations in the surface layer (small-sized particles) were high enough to be measurable, or organic matter degradation was fast. In addition, the spatial variability (aggregated distribution) of mussel drop-offs could have induced variability in organic matter within treatments that led to non-significant temporal variations in sediment organic content at M2.

The POC:PON ratios measured in the first $2 \mathrm{~cm}$ of sediment decreased slightly from July and August to September. Organic matter would be more degraded in July and August than in September; this could be partly explained by variations in temperature. Indeed, in parallel, silica, ammonium and phosphate fluxes varied over the 3 mo at the 2 yr old mussel site. Maxi- 
mum ammonium and phosphate releases in July and August would be linked to the high water temperatures in early summer. Indeed, high water temperature and organic matter enrichment from M2 could have stimulated bacterial proliferation (La Rosa et al. 2001, Lomstein et al. 2006) and favour organic matter mineralisation that induced greater nutrient releases. The decreasing water temperature in September would be responsible for decreasing metabolic activities and lower ammonium and phosphate releases. The highest ammonium fluxes (observed in August) could also result from the decomposition of large numbers of decaying mussels (Balzer et al. 1983, Lomstein et al. 2006) resulting from mass mortality events. In addition, lower oxygen concentration in the overlying water in August compared to September would have favoured ammonium and phosphate releases (Balzer et al. 1983, Mazouni et al. 1996, Lomstein et al. 2006). Dissolution of biogenic silica is also positively related to temperature (Lerat et al. 1990), which could explain the high silica releases observed in August. However, biogenic silica (BSi) dissolution is a long-term process (Baudinet et al. 1990), while ammonium and phosphate fluxes originate mainly from the rapid degradation of fresh organic material by macrofauna and bacteria. The slow dissolution of BSi accumulating in the sediment could explain the lower releases observed in July (although water temperature was high) compared with August. In contrast to silicate, ammonium and phosphate fluxes, no temporal variation was observed for nitrite and nitrate fluxes in the lagoon. Nitrite and nitrate regenerations were not correlated with temperature, in agreement with observations by Mazouni et al. (1996).

Oxygen consumption increased from July and August to September. Although water temperature and oxygen consumption are often positively correlated (Hargrave 1969, Pearson \& Rosenberg 1978, Hatcher et al. 1994), oxygen consumption in this study increased whereas temperature decreased. Since oxygen consumption depends on the benthic community biomass (Mazouni et al. 1996) and abundance (Nickell et al. 2003), a parallel could be drawn between the increases in oxygen consumption and benthos biomass/abundance which originated from recruited organisms. Nevertheless, oxygen consumptions in GEL (from $133 \mathrm{mg}$ $\mathrm{O}_{2} \mathrm{~m}^{-2} \mathrm{~h}^{-1}$ in July and August to $408 \mathrm{mg} \mathrm{O} \mathrm{m}^{-2} \mathrm{~h}^{-1}$ in September) are high in comparison with previously reported values under mussel cultures in Canada (e.g. $48 \mathrm{mg} \mathrm{m}^{-2} \mathrm{~h}^{-1}$ : Hatcher et al. 1994) and in France (e.g. $64 \mathrm{mg} \mathrm{m}^{-2} \mathrm{~h}^{-1}$ : Baudinet et al. 1990). The GEL values correspond to oxygen demands measured under salmon cages in the Bay of Fundy $\left(132 \mathrm{mg} \mathrm{m}^{-2} \mathrm{~h}^{-1}\right.$ : Hargrave et al. 1993) and in Loch Creran $\left(579 \mathrm{mg} \mathrm{m}^{-2} \mathrm{~h}^{-1}\right.$ : Nickell et al. 2003). In contrast, the mean macrofauna biomasses observed in GEL (1.56 in July, 1.75 in August, $4.75 \mathrm{~g} \mathrm{DW} \mathrm{m}^{-2}$ in September) were very low and corresponded to values observed under oyster lines in the Thau lagoon during an anoxic event (Mazouni et al. 1996) or in areas impacted by mussel lines in South Africa $\left(<5 \mathrm{~g} \mathrm{DW} \mathrm{m}^{-2}\right.$ in mussel site vs. 20 to $60 \mathrm{~g}$ DW $\mathrm{m}^{-2}$ in control sites: Stenton-Dozey et al. 2001). Respiration by the low macrofaunal biomass in GEL cannot explain the high oxygen consumption rates recorded. Hargrave et al. (1993) related the high oxygen uptake under salmon cages with sediment sulfide accumulation and not with water temperature. In GEL, reduced sediment could promote sulfate reduction (Cranford et al. 2003) and lead to sulfide accumulation in surface sediments (Dahlbäck \& Gunnarsson 1981). Indeed, high sulfide concentrations were observed in the first $1 \mathrm{~cm}$ of sediment in August 2003 (mean 1747 to $2407 \mathrm{\mu M} \mathrm{l}^{-1}$, depending on site; M. D. Callier unpubl. data) and characterised hypoxic sediment (Wildish et al. 1999). Oxygen uptake should be driven by oxidation of these reduced metabolites. The production of hydrogen sulfide and the hypoxic conditions, which are toxic for macrofauna (Hargrave et al. 1993, Gray et al. 2002, Miron et al. 2005), would explain the low macrobenthic biomass and the occurrence of smallsized individuals. The increased oxygen demand would originate partly from the respiration of newly recruited organisms, and mainly from the oxidation of sulfides accumulated during the summer. Sulfide oxidation would be favoured by irrigation activities of small-sized organisms (Nickell et al. 2003).

\section{CONCLUSIONS AND PERSPECTIVES}

As expected, the 2 yr old suspended mussel lines had a greater influence on the benthic environment than the 1 yr old mussel lines in Grande-Entrée lagoon. The 2 yr old mussel lines induced local organic enrichment and increased benthic nutrient fluxes whereas the $1 \mathrm{yr}$ old mussel lines did not. In the oligotrophic GEL, the benthic area beneath the 2 yr old mussel lines acts as source of nutrients (particularly of nitrogen and silica) in the summer, whose magnitude varies according to bottom-water and sediment characteristics. This source could induce summer variations in the nutrient standing stocks and ratios of overlying waters. In contrast, the 1 yr old mussel lines seemed not to influence nutrient cycling. The results of this study highlight the importance of dissociating the influence of differences in age of the culture organisms when modelling the carrying capacity of marine ecosystems comprised of bivalve cultures of various age classes.

Considering their low macrofaunal biomass, high oxygen demand (this study), low redox, high sulfide 
concentration and the presence of opportunistic species (M. D. Callier unpubl. data) in their sediment, it is likely that the control sites were affected by organic load. Benthic metabolism in GEL could be mainly driven by microbial-mediated oxidation of organic matter and reduced inorganic metabolites. Reduced conditions in the sediment could be natural in GEL, since the sediment of some deep zones has already been described as 'black, soft, and stinking' in 1982, i.e. before aquaculture development (Poirier \& Myrand 1982). In 1982, the maximum depth of GEL was $10 \mathrm{~m}$ (Poirier \& Myrand 1982) compared to $7.2 \mathrm{~m}$ in 2003 (YSI probe data, this study). Mussel biodeposits could have accumulated in sediment of the deeper zones since 1985 and partly explain this silting. Continuous biodeposit accumulation could have progressively brought about degradation of the benthic environment in the deeper zones of the lagoon.

Acknowledgements. We thank J. Clavier for valuable help in designing the benthic chamber systems, P. Robichaud and B. Chenard for help on waterproof systems, and Y. Samson, S. Chartrand and J. S. Ouellet for advice on electronic systems. We express gratitude to Fisheries and Oceans (MontJoli) for boat facilities and to G. Arseneault and R. Lavallée for boat piloting. We also thank the members of the BECCS (Bivalve Environmental Carrying Capacity Studies) research team (M. Callier, F. Hartog, C. McKindsey, J. Tomac and A. Weise) and O. Pitre for their help in the field. Thanks to C. Eloquin who provided access to his mussel farm and to S. Roy for lending the fluorometer. We are grateful to G. Tita for his help showing us around the Îles-de-la-Madeleine and for his knowledge about mussel and scallop farms in GEL. We thank M. Callier for providing data on sedimentation rates and benthic environment, and L. MacLaughlin, who performed the nutrient analyses on A. Gagné's equipment, A. Masson who did CHN analyses, and R. Larocque who provided furnaces. Finally, we thank L. Devine for criticising the manuscript and for linguistic improvements. This study was funded by the Aquaculture Collaborative Research and Development Program to P.A., the Department of Fisheries and Oceans Canada, the Réseau Aquaculture Québec, the Société de Développement de l'Industrie Maricole, and ISMER.

\section{LITERATURE CITED}

Balzer W, Grasshoff K, Dieckmann P, Haardt H, Petersohn U (1983) Redox-turnover at the sediment-water interface studied in a large bell jar system. Oceanol Acta 6:337-344

Baudinet D, Alliot E, Berland B, Grenz C, Plante-Cuny M, Plante R, Salen-Picard C (1990) Incidence of mussel culture on biogeochemical fluxes at the sediment-water interface. Hydrobiologia 207:187-196

Boucher G, Clavier J (1990) Contribution of benthic biomass to overall metabolism in New Caledonia lagoon sediments. Mar Ecol Prog Ser 64:271-280

Byers SC, Mills EL, Stewart PL (1978) A comparison of methods of determining organic carbon in marine sediments, with suggestions for a standard method. Hydrobiologia 58: $43-47$
Callier MD, Weise AM, McKindsey CW, Desrosiers G (2006) Sedimentation rates in suspended mussel farm (GreatEntry Lagoon, Canada): biodeposit production and dispersion. Mar Ecol Prog Ser 322:129-141

Christensen PB, Glud RN, Dalsgaard T, Gillespie P (2003) Impacts of long line mussel farming on oxygen and nitrogen dynamics and biological communities of coastal sediments. Aquaculture 218:567-588

Cranford P, Dowd J, Grant J, Hargrave B, McGladerry S (2003) Ecosystem level effects of marine bivalve aquaculture. Can Tech Rep Fish Aquat Sci 2450:51-93

Dahlbäck B, Gunnarsson LAH (1981) Sediment and sulfate reduction under mussel culture. Mar Biol 63:269-275

Danovaro R, Gambi C, Luna GM, Mirto S (2004) Sustainable impact of mussel farming in the Adriatic Sea (Mediterranean Sea): evidence from biochemical microbial and meiofaunal indicators. Mar Pollut Bull 49:325-333

Deslous-Paoli JM, Souchu P, Mazouni N, Juge C, Dagault F (1998) Relations milieu-ressources : impact de la conchyliculture sur un environnement lagunaire méditerranéen (Thau). Oceanol Acta 21:831-842

Glud RN, Blackburn N (2002) The effects of chamber size on benthic oxygen uptake measurements: a simulation study. Ophelia 56:23-31

Grant J, Hatcher A, Scott DB, Pockligton P, Schafer CT, Winters GV (1995) A multidisciplinary approach to evaluating impacts of shellfish aquaculture on benthic communities. Estuaries 18:124-144

Gray JS, Wu RS, Or YY (2002) Effects of hypoxia and organic enrichment on the coastal marine environment. Mar Ecol Prog Ser 238:249-279

Grenz C, Hermin MN, Baudinet D, Daumas R (1990) In situ biogeochemical and bacterial variation of sediments enriched with mussel biodeposits. Hydrobiologia 207:153-160

Grenz C, Moutin T, Picot B, Massé H (1991) Comparaison de deux méthodes de mesure de flux de nutriments à l'interface eau-sédiment: méthode des peepers et méthode des chambres benthiques. C R Acad Sci Sér III 313:239-244

Grenz C, Alliot E, Baudinet D, Helis L, Masse H (1992) Influence des opérations de dévasage sur les flux de nutriments à l'interface eau-sédiment (Bassin de Thau-France). Vie Milieu 42:157-164

Hargrave BT (1969) Similarity of oxygen uptake by benthic communities. Limnol Oceanogr 14:801-805

Hargrave BT, Duplisea DE, Pfeiffer E, Wildish DJ (1993) Seasonal changes in benthic fluxes of dissolved-oxygen and ammonium associated with marine cultured Atlantic salmon. Mar Ecol Prog Ser 96:249-257

Hartstein ND, Rowden AA (2004) Effect of biodeposits from mussel culture on macroinvertebrate assemblages at the sites of different hydrodynamic regime. Mar Environ Res 57:339-357

Hatcher A, Grant J, Schofield B (1994) Effects of suspended mussel culture (Mytilus sp.) on sedimentation, benthic respiration and sediment nutrients dynamics in a coastal bay. Mar Ecol Prog Ser 115:219-235

Holmes RM, Aminot A, Kérouel R, Hooker BA, Peterson BJ (1999) A simple and precise method for measuring ammonium in marine and freshwater ecosystems. Can J Fish Aquat Sci 56:1801-1808

Hulbert SH (1984) Pseudoreplication and the design of ecological experiments. Ecol Monogr 54:187-211

Jenkins MC, Kemp M (1984) The coupling of nitrification and denitrification in two estuarine sediments. Limnol Oceanogr 29:609-619

Kautsky N, Evans S (1987) Role of biodeposition by Mytilus edulis in the circulation of matter and nutrients in a Baltic 
coastal ecosystem. Mar Ecol Prog Ser 38:201-212

Koutitonsky VG, Tita G (2006) Temps de renouvellement des eaux dans la lagune de Grande-Entrée, Îles-de-la-Madeleine (Rapp Rech-Dev 151). Ministère de l'Agriculture, des Pêcheries et de l'Alimentation du Québec (MAPAQ), Québec, p 1-73

Koutitonsky VG, Navarro N, Booth D (2002) Descriptive physical oceanography of Great-Entry lagoon, Gulf of St Lawrence. Estuar Coast Shelf Sci 54:833-847

La Rosa T, Mirto S, Marino A, Alonzo V, Maugreri TL, Mazzola A (2001) Heterotrophic bacteria community and pollution indicators of mussel farm impact in the Gulf of Gaeta (Tyrrhenian Sea). Mar Environ Res 52:301-321

Lerat Y, Boucher G, Le Corre P (1985) Echanges à l'interface eau-sédiment dans un secteur côtier à forte déposition (parc ostréïcole) cas de l'ammonium et des nitrates. Cah Biol Mar 26:393-408

Lerat Y, Lasserre P, Le Corre P (1990) Seasonal changes in pore water concentrations of nutrients and their diffusive fluxes at the sediment-water interface. J Exp Mar Biol Ecol 135:135-160

Lomstein BA, Guldberg LB, Hansen J (2006) Decomposition of Mytilus edulis: the effect on sediment nitrogen and carbon cycling. J Exp Mar Biol Ecol 329:251-264

Mattsson J, Lindén O (1983) Benthic macrofauna succession under mussels, Mytilus edulis L. (Bivalvia), cultured on hanging long-lines. Sarsia 68:97-102

Mazouni N, Gaertner JC, Deslous-Paoli JM, Landrein S, Geringer d'Oedenberg M (1996) Nutrient and oxygen exchanges at the water-sediment interface in a shellfish farming lagoon (Thau, France). J Exp Mar Biol Ecol 205:91-113

Miron G, Landry T, Archambault P, Frenette B (2005) Effects of mussel culture husbandry practices on various benthic characteristics. Aquaculture 250:138-154

Myrand B, Gaudreault J (1995) Summer mortality of blue mussels (Mytilus edulis Linneaus, 1758) in the Magdalen Islands (southern Gulf of St Lawrence Canada). J Shellfish Res 14:395-404

Navarro JM, Thompson RJ (1997) Biodeposition by the horse mussel Modiolus modiolus (Dillwyn) during the spring diatom bloom. J Exp Mar Biol Ecol 209:1-13

Nickell LA, Black KD, Hughes DJ, Overnell J, Brand T, Nickell TD, Breuer E, Harvey SM (2003) Bioturbation, sediment fluxes and benthic community structure around a salmon cage farm in Loch Creran, Scotland. J Exp Mar Biol Ecol 285/286:221-233

Nilsson H, Rosenberg R (2000) Succession in marine benthic habitats and fauna in response to oxygen deficiency: analysed by sediment profile-imaging and by grab samples. Mar Ecol Prog Ser 197:139-149

Pearson TH, Rosenberg R (1978) Macrobenthic succession in relation to organic enrichment and pollution of the marine environment. Oceanogr Mar Biol Annu Rev 16:229-311

Poirier L, Myrand B (1982) Élevage de la moule bleue, Mytilus edulis, dans les lagunes des Îles-de-la-Madeleine (Québec). (Trav Pêch Québec 49), MAPAQ, Direction Générale des Pêches Maritimes, Québec, p 1-64

Redfield AC, Ketchum PH, Richards FA (1963) The influence of organisms on the composition of seawater. In: Hill (ed) The sea, ideas and observations on progress in the study of the seas, Vol 2, The composition of sea water: comparative and descriptive oceanography. Wiley Interscience, London, p 27-77

Richard M, Archambault P, Thouzeau G, Desrosiers G (2006) Influence of suspended mussel lines on the biogeochemi- cal fluxes in adjacent water in the Îles-de-la-Madeleine (Québec, Canada). Can J Fish Aquat Sci 63:1198-1213

Roy S, Mayzaud P, Souchu P (1991) Environnement physicochimique et trophique d'un site mytilicole aux Îles-de-laMadeleine (Québec): II. Matière particulaire, composition biochimique, et productivité primaire. In: Therriault JC (ed) Le golfe du Saint Laurent: petit océan ou grand estuaire? Can Spec Publ Fish Aquat Sci 113:219-230

Smaal AC (1991) The ecology and cultivation of mussels: new advances. Aquaculture 94:245-261

Smayda TJ (1990) Novel and nuisance phytoplankton blooms in the sea: evidence for a global epidemia. In: Granéli, Sundström, Edler (eds) Toxic marine phytoplankton. Elsevier Science, New York, p 29-40

Sornin JM, Feuillet M, Héral M, Fardeau JC (1986) Influence des cultures d'huîtres Crassostrea gigas sur le cycle du phosphore en zone intertidale: rôle de la biodéposition. Oceanol Acta 9:313-322

Souchu P, Mayzaud P (1991) Inorganic nutrients in precipitation over the Magdalen Islands area (Quebec, Canada) and their impact on the primary productivity of the lagoons. Atmospheric Res 26:543-554

Souchu P, Mayzaud P, Roy S (1991) Environnement physicochimique et trophique d'un site mytilicole, Îles de la Madeleine (Québec): I. Evolution estivale des composés de l'azote, du phosphore et du silicium. In: Therriault JC (ed) Le golfe du Saint Laurent: petit océan ou grand estuaire? Can Spec Publ Fish Aquat Sci 113:209-218

Stenton-Dozey J, Probyn T, Busby A (2001) Impact of mussel (Mytilus galloprovincialis) raft-culture on benthic macrofauna, in situ oxygen uptake, and nutrient fluxes in Saldanha Bay, South Africa. Can J Fish Aquat Sci 58: 1021- 1031

Thouzeau G, Grall J, Clavier J, Chauvaud L and 5 others (2007) Spatial and temporal variability of benthic biogeochemical fluxes associated with macrophytic and macrofaunal distribution in the Thau lagoon. Estuar Coast Shelf Sci 72:432-446

Tréguer P, Le Corre P (1975) Manuel d'analyse des sels nutritifs dans l'eau de mer. LOC-UBO, Brest

Underwood AJ (1996) Detection, interpretation, prediction and management of environmental disturbances: some roles for experimental marine ecology. J Exp Mar Biol Ecol 200:1-27

Underwood AJ (1997) Experiments in ecology: their logical design and interpretation using analysis of variance. Cambridge University Press, Cambridge, UK

Van der Loeff MMR, Anderson LG, Hall POJ, Iverfeldt A, Josefson AB, Sundby B, Westerlund SFG (1984) The asphyxiation technique: an approach to distinguish between molecular diffusion and biologically mediated transport at the sediment-water interface. Limnol Oceanogr 29: $675-686$

Welsh DT (2003) It's a dirty job but someone has to do it: the role of marine benthic macrofauna in organic matter turnover and nutrient recycling to the water column. Chem Ecol 19:321-342

Wildish DJ, Akagi HM, Hamilton N, Hargrave BT (1999) A recommended method for monitoring sediments to detect organic enrichment from mariculture in the bay of Fundy. Can Tech Rep Fish Aquat Sci 2286:1-31

Wildish DJ, Hargrave BT, Macleod C, Crawford C (2003) Detection of organic enrichment near finfish net-pens by sediment profile imaging at SCUBA-accessible depths. J Exp Mar Biol Ecol 285/286:403-413 